\title{
"Not of this World": The Emergence of the Old Colony Mennonites
}

\author{
Hans Werner ${ }^{1}$ \\ Associate Professor \\ Department of History \\ University of Winnipeg
}

\begin{abstract}
By the early twenty-first century, Old Colony Mennonites constituted a diaspora across the Americas. They maintained distinctive conservative dress and selectively rejected aspects of modern technology. While the label "Old Colony" became current in Manitoba in the 1870s, their conserving orientation reaches back to church divisions in The Netherlands in the sixteenth century. After a sojourn in West Prussia, they migrated to Russia in the eighteenth century and then to the prairies of Manitoba in the 1870s. The rapid industrialization of Russia and Canada sharpened their Anabaptist sense of being separate from the world and stimulated a reaction to particular innovations: new ways of singing, progressive education, pietism, and market agriculture. By 1890, the lines were drawn and, with a re-registration of church members, the Old Colony Church was a reality. World War I aggravated the conserver-oriented Old Colony Mennonites, stimulating a migration to Mexico - and a culture of migration - to avoid contact with the modern world.
\end{abstract}

\section{Keywords}

Education; Flemish; Frisian; Bishop Johann Wiebe; Manitoba; modernization; singing

\section{Acknowledgements}

I am indebted to reviewers who provided thoughtful suggestions on earlier versions of this article.

Werner, Hans. 2016. "Not of this World': The Emergence of the Old Colony Mennonites." Journal of Amish and Plain Anabaptist Studies 4(2):121-32. 


\section{Introduction}

Old Colony Mennonites today constitute a diaspora spread across the Americas. With nodes of settlement in places as disparate as Mexico, Belize, Bolivia, Paraguay, Argentina, Ontario, Manitoba, Alberta, Texas, Kansas, Peru, and Columbia, “Old Colony” Mennonites have become a transnational community. Although displaying myriad variations in expression, Old Colony Mennonites have maintained a strong sense that the Christian should live separate from the world. In broad terms, separateness is expressed in the rejection of technology, the maintenance of distinctive dress, and the emphasis of communitarian - as opposed to individualistic — values. They have also placed greater emphasis on discipline and the use of the ban than have their progressive Anabaptist coreligionists.

While fragmentation into "conserver" and "progressive" factions (Friesen 1989, 61) can be seen throughout Mennonite history, the emergence of the Old Colony Mennonites is significant in that such a large, growing group has continued to maintain anti-modern orientations while the world is hurtling from modernity to an unknown beyond. The discussion that follows engages the question of what gave rise to the Old Colony Mennonite phenomenon, examining the interplay of a sixteenth century Dutch Mennonite schism, events during the Mennonites' time in both the Russian Empire and Canada, the leap forward in innovation in Manitoba upon the Mennonites' arrival, and the role of key historic personalities. In many ways, this is a story of continuity rather than change. Divisions that emerged in the relatively closed Mennonite colonies in the Russian Empire continued and re-emerged in the context of migration to Manitoba. While the more separation-oriented Mennonites in Russia believed that through migration the tensions between them and their coreligionists could be bypassed, the opposite happened. Their apparently like-minded fellow immigrants now became the protagonists on a seemingly relentless path to closer conformity with the world.

\section{Schism in the Dutch Church}

The ethos of Old Colony Mennonites can be traced to the 1566 split in the Dutch Mennonite congregations that gave rise to the Flemish and Frisian factions. Although the division was not in the end based on ethnicity, it began with objections in Harlingen to the election of Flemish refugee Jeroen Tinnegieter as preacher in the Franeker congregation. The churches in Harlingen, Franeker, Leeuwarden and Dokkum had formed a union in 1560 based on agreement to 19 articles regulating church life. One of the articles specified that a preacher chosen by one congregation also served the other three. Tinnegieter responded by withdrawing his congregation from the union of four churches. Disagreement within the Franeker congregation about the withdrawal led to a group worshipping separately, ultimately giving rise to a division that soon spread to the Harlingen and other congregations. ${ }^{2}$ Twenty years later, a further division of the Flemish resulted in the more conservative Old Flemish (Huiskoopers), who held even more closely to the ban, strict discipline, and plain living and dress. ${ }^{3}$ The FrisianFlemish split marred relations between the Dutch Mennonites throughout the later decades of the 
sixteenth century. Even after disappearing in The Netherlands, the schism continued to live on among the Dutch immigrants to Prussia and was revived among the Mennonites who migrated to the Russian Empire beginning in 1789 (Ens 1990).

Historians have been divided in their explanations for the recurring divisions of Mennonites into more conserving and progressive leanings, with their analysis often a result of their own vantage points. Given that most formal histories of Mennonites have been written during the twentieth century, the history of the traditionalist groups has often been disparaged. An exception in the case of the Dutch schism of the sixteenth century is Henry Schapansky (2006), an apologist for the Flemish, who characterizes them as having a more "democratic community-oriented outlook" and being "more traditionally Anabaptist and stricter" than the Frisians. Frisians, on the other hand, were "more individualistically oriented" and more autocratic (46-47). P.M. Friesen (1980), a Mennonite Brethren historian, dismisses the Flemish as having "a confessional rigidity and exclusivity combined with a minimum of piety and morality." Frisians, in his view, "acted in a more brotherly fashion to believers in other denominations, demonstrated a more genuine piety and a greater tendency to cultural and church improvement" (53). Other observers have focused more specifically on the social and cultural dimensions of the two leanings. An oft-repeated characterization has the Flemish objecting to the Frisian quantities of linens and household goods, while the Frisians objected to Flemish ways of living and dressing (Koop 2004, 51; Schapansky 2006, 44). According to Gerald Studer (1984), "the Flemish were worldly in respect to their dress; the Frisian in their homes" (508). It must be noted that creating a dichotomy of Flemish as conserving and Frisians as progressive is an oversimplification. Greater and lesser emphasis on traditional positions was a feature of both groups, resulting in constant movement and further subdivision. Frisians often revolted against the tendency to be less separate, while the Flemish continually drifted toward accommodation with the world.

What emerged as the "Old Colony" in Manitoba in the nineteenth century-and then reproduced in a growing diaspora - was to some extent the legacy of a 300-year tradition of tension about (1) what it meant for the Christian to be separate from the world, and (2) how a member of the community (Gemeinde) should be dealt with when he/she failed to uphold its religious and social norms. While the rejection of new technologies and fashion were often visible expressions of conserver-oriented Mennonites, ultimately these two questions lay at the root of tensions between them and their coreligionists.

\section{Developments in Russia}

Mennonites began migrating to the Russian Empire in 1789. The initial movement consisted primarily of Flemish Mennonites, who established a colony on lands where the Chortitza River emptied into the Dnieper River. A second migration in 1803, also predominately Flemish in origin, established the larger Molotschna Colony. Since the Chortitza Colony was established earlier, it became known as the "Old Colony." Shortages of land for the large 
families soon created problems and, in 1835, the Chortitza Colony established the daughter colony of Bergthal. By the 1870s, when the migration to North America occurred, there were other daughter colonies - including Fuerstenland, which was on land leased from a Russian nobleman. Bergthal and Fuerstenland were daughter colonies of the Chortitza colony that figured prominently in the migration to Manitoba and the eventual establishment of the Old Colony Church.

The Flemish-Frisian schism did not alone contribute to the emergence of the Old Colony Church. Both the Russian Empire and the new Dominion of Canada were on the brink of becoming modern industrial societies. In both countries, the changes Mennonites confronted brought to the forefront the question of the relationship between the Christian and the world. For the Russian context, John J. Friesen notes the influence of the progressive Mennonite leader Johann Cornies, who - while championing village organization, village and yard layout, agricultural practices and efficiency, and economic improvement-sought to reform the education system, thereby "expos[ing] the students to influences and ideas from the larger world" (Friesen 2011, 7). While progressive Mennonites hold up Cornies as the stimulus for the flowering of Mennonite social and economic success, many Mennonites of his day were much less enamored with his leadership because of his autocratic tendencies. David Epp, a contemporary of Cornies, confided to his diary that "the behavior of Joh. Cornies is more despotical than Christian" (Dyck 1984, 14). A worry for the more conserver-oriented daughter colonies was the advance of worldliness accompanying Cornies's educational reforms (Ens 1989, 80-82; Friesen 2011, 7).

A second disturbing development came with the introduction of new ways of singing. Mennonites in Russia sang using the Oele Wies ("old melody"). A song was chosen by the Vorsänger, who sat in the front of the church. The tempo was slow and the melody was often embellished to the point of its original line being hardly discernible. Frequently, at the end of a verse, when the congregation fell silent, the Vorsänger continued with an embellished series of notes that led into the next verse, at which point the congregation joined in again.

When the movement to change the way of singing was underway, critics described the old way of singing as being "forced out of their throats and is shrill and loud beyond measure" (Berg 1996, 79-81). Heinrich Heese-who began teaching in the colonies in 1818-complained about the disharmony and "distorted singing" of Mennonites. As early as 1837, Heinrich Franz worked to reform the singing of the school children he taught and, in addition to returning to the original melodies of hymns, developed a notation system known as Ziffern - or ciphers - that eliminated the spontaneous changing of songs (Berg 1996, 80). The introduction of the new way of singing in congregational worship was accompanied by deep and lasting controversy. In the diaries of Minister Jacob Epp, the first entries that refer to the new way of singing are in January 1860, when Epp was visited by a Heinrich Olfert, who had led a song in the worship service in a neighboring village using the new melodies. Epp records in his diary that Ohm Isaak Klassen had "compared such singing to a pub song" and that Klassen's brother and another man had 
immediately left the service. The controversy in Epp's church district raged on until, finally, in March 1871, some ten years after the initial entry, he could record that he thought the controversy was dying down (Toews 1985, 4-7). Significantly the Bergthal daughter colony did not adopt the new melodies, and a short three years later the migration to North America began.

Another important influence that widened the difference between conserver and progressive orientations among Russian Mennonites was the emergence of Pietism. While some of the late migrants to Russia had been influenced by Pietism before they arrived, the most visible evidence of Pietistic influence was the emergence of the Mennonite Brethren church in the 1860s. Their emphasis on personal conversion and repentance was accompanied by immersion baptism and, among other innovations, the adoption of new melodies and choral singing. Much of this expression, viewed as renewal by participants, was anathema to those emphasizing separation from the world. The requirement to effectively deny their original baptism to become Mennonite Brethren and the excesses of exuberance displayed by some early adherents were particularly offensive to more traditional Mennonites (Toews 1984).

\section{New Tensions in Manitoba}

By the time the reforms of Tsar Alexander II challenged all Mennonites on the question of military exemption, the rift within the Mennonites of Russia had already become a chasm. As James Urry notes, the emigration of the 1870s was really "a massive parting of the ways" (Urry 1989, 218). The settlement choices made by emigrating Mennonites reflected the age-old tensions of where best to live separately from the world. The more separatist orientation of the Bergthal colony prompted those emigrants to choose Manitoba, where the promise of military exemption and the ability to live together in a block settlement - and hence separate from the world - was more assured. Paul Tschetter, one of the Hutterian delegates who came to inspect the land in North America in 1873, recorded a conversation with the Bergthal delegate Heinrich Wiebe, the latter noting that he does not find the United States suitable because a guarantee of military exemption would likely not be obtainable. His assessment before even seeing Manitoba was that "an English government would be more liberal" in "guaranteeing military exemption" (Hofer 1931, 199). The more progressive Mennonite migrants from Russia chose Kansas, while migrants from the Chortitza colony and its daughter colonies - Bergthal, Fuerstenland, Kleine Gemeinde, and several smaller ones - settled the East and West Reserves of Manitoba. In particular, the West Reserve would become home to settlers from the Fuerstenland and Chortitza colonies who favored more traditional ways.

The conserver-oriented Mennonite desire to arrest modernization would not be realized even by those choosing Manitoba. Manitoba in the 1870s was perched on the brink of massive changes that represented nothing short of a leap forward in new technologies, economies, and ideas about public education. Within 25 years of the Mennonite settlement in Manitoba, the railway revolutionized the countryside. Subsistence agriculture was transformed to marketoriented wheat production. The household economy was based increasingly on an exchange of 
money rather than production for basic needs. Market towns sprang up along the railway lines, including along a line that went right through the West Reserve. These market towns offered the lure of consumer goods and "the world."

The new immigrants were also unable to escape internal controversies that existed in Russia, specifically: (1) the controversy of singing in the worship service, and (2) the controversy of education, which the state was increasingly imposing upon them. In addition, the creation of municipal government was a new imposition of "the world" on the Mennonite sense of how the Christian should live. If developments in Russia moved Mennonites toward a more progressive orientation, the pace of change in Manitoba produced a reaction that sought to conserve previous traditions.

The Canadian government had set aside two blocks of land for Mennonite settlement: the East Reserve was separated by the Red River and approximately 35 miles from the second settlement, the West Reserve. The Bergthal Colony immigrants initially settled on the East Reserve under the leadership of Bishop Gerhard Wiebe. While the Fuerstenland and Chortitza origin immigrants waited at the Dufferin immigration sheds on the Red River for their lands to be surveyed, they organized themselves as a congregation. They agreed to unite under one Bishop, Johann Wiebe of Fuerstenland Colony, the 39-year-old nephew of Bishop Gerhard Wiebe. When they settled on the higher ground on the western half of the West Reserve, they formally organized as the Reinlaender Mennoniten Gemeinde (Zacharias 2011, 45-48). While they settled on two different blocks of land, Mennonites in the two settlements initially believed they shared a similar orientation. There would, however, soon be deeply divisive issues that set them on different paths.

One issue that the new congregations in Manitoba faced almost immediately was the question of how they would sing. Historical writings examining the emergence of the Old Colony have tended to gloss over the divisive issue of singing, which was transplanted with the settlers that came to Manitoba. Calvin Redekop's version of how the question arose suggests some confusion about which elder initiated the discussion of what type of singing the new settlement should have. He suggests Bergthaler Bishop Gerhard Wiebe initially recommended they return to the old melodies, persuading his nephew to adopt that position (Redekop 1969, 8). Peter Zacharias, on the other hand, cites an 1876 letter written by Johann Wiebe that suggests Gerhard Wiebe "supported the reintroduction of the old tunes quite strongly" (Zacharias 2011, 192). If Gerhard Wiebe favored the old melodies, he was seemingly unable to persuade his congregation. In the end, the Bergthaler of the East Reserve did not adopt the old melodies and thus "the difference between the two groups was accentuated" (Redekop 1969, 8). To compound the challenge of establishing the desired order on the West Reserve, some Bergthaler who found the land on the East Reserve unsuitable began moving to the eastern portion of the West Reserve in 1879. The two groups that had taken different positions on the question of singing now lived in close proximity. 
A second point of contention was the system of local government. In Russia, Mennonites had lived in relatively autonomous colonies with a system of local government that combined civic and religious leadership. The duality of this system had not been without tension, and the settlers of the West Reserve resolved to not repeat these tensions. As Peter D. Zacharias (2011) notes, certainly in the mind of Bishop Johann Wiebe, "only one colony administration and only one church served the villages of the West Reserve" (192). The newly arrived Mennonites did not anticipate the state's desire to impose a system of local government upon them. In 1879, the Manitoba government passed the Municipal Act, dividing the province into local government districts. However, local initiative was required to establish these municipalities. While the Bergthaler who had settled on the East Reserve accepted municipal government, the West Reserve ignored the legislation. The establishment of local government coincided with the move from the East Reserve to the West of Bergthaler. The migrants were not inclined to submit to the colony administration of the Chortitzer and Fuerstenland settlers who had arrived before them.

Amid the turmoil of the singing controversy, the beginnings of a Bergthaler migration to the eastern half of the West Reserve, and the government's desire to establish its system of local government, West Reserve Bishop Johann Wiebe called for a brotherhood meeting that proved to be defining. An announcement went out to the members of the church calling for a meeting in the Reinland Church on October 5, 1880. Zacharias suggests that although there was a broader basis for the dissension in the one Gemeinde created at the Dufferin immigration sheds in 1875, the flash point of disagreement revolved around the singing question. The announcement for the October 1880 brotherhood was clear; families would have to decide formally to stay in the church and submit to its direction or to leave it. The outcome of the meeting called for a reregistration with the Bishop. Zacharias (2011) notes that while many registered, "many did not" (193). The October 1880 brotherhood meeting marks the official beginning of what are commonly referred to as Old Colony Mennonites.

The events that led up to the 1880 brotherhood meeting and its outcome would not have assured a continuing, identifiably Old Colony community. There were, however, continuing pressures that forced Manitoba Mennonites in the opposite direction of that chosen by the Old Colony. The question of education, already an issue in Russia, once again challenged Mennonites who favored separation from the world. In the 1890s, Manitoba was embroiled in a controversy over French Catholic and English Protestant schooling and government funding of a dual system of education. Although the controversy left the Old Colony, who operated private church run schools unmolested, it signaled the beginnings of state intervention in education. Some Manitoba Mennonites - though not the Old Colony - actively promoted progressive education, and, by 1902, Mennonite areas had 41 public school districts (Ens 1994, 111).

A blow to those accepting public education was the government's introduction of policies designed to foster patriotism. In 1906, Manitoba's Premier Roblin passed legislation requiring the flag to be flown at all public schools. While the Old Colony Mennonites had never adopted 
public schools or government funding, the tone of the government was ominous. At a political meeting, Premier Roblin outlined his reasoning for the flag policy in strident nationalistic tones:

I think the man who comes from a foreign country in order to benefit his circumstances, and who objects to perpetuating the glories of our flag and declines to have his children infused with British patriotism, is a man that is undesirable (Ens 1994, 110-11).

With dismay, Old Colony Mennonites watched both the moves to more progressive education among their more liberal coreligionists and the increasingly patriotic and - in their viewmilitaristic attitude of the state towards the role of education. The state's educational policies and conservative Mennonite resistance reached crisis proportions in the context of World War I, when the state enacted compulsory school attendance and forced public schools on all Mennonite districts. Considered to be the area of the most intense resistance - and hence one of the last places to address - was the area of the Old Colony settlement on the West Reserve. The public school districts created in 1920 in the heart of Old Colony villages were named without regard for the localities where they were situated and bore English names such as Snowdon, Clyde, Thames, and Exeter (Ens 1994, 130-32). The imposition of public schooling became the main reason for the migration of Old Colony Mennonites to Mexico in the 1920s and offered the clearest reinforcement of the Old Colony identity that had been coalescing since their settlement in Manitoba.

Mennonites in Manitoba could also not escape the inroads of Pietism that had offended some of them in Russia. In 1883, Mennonite Brethren in the United States sent Heinrich Voth and David Dyck as "missionaries" to Manitoba, and, by 1889, a Mennonite Brethren Church was organized just north of Winkler in the West Reserve. There were other religious developments that challenged the Old Colony Church. A more expressive form of religiosity also captured the imagination of the village of Hoffnungsfeld and a flood of missionaries from the United States General Conference made visits to the villages on the West Reserve. As congregational historian David Friesen notes, the "work of the missionaries was often more an effort at modernization than mission" (Friesen 1995, 21). The influences of evangelicalism entering the world of the Old Colony in Manitoba soon produced a defensive posture against religious innovation. Rather than stimulating new ways of expressing their faith, these efforts sharpened the boundaries of Old Colony identity.

Although West Reserve Bishop Johann Wiebe did not live to see the crisis of World War I, his personality dominates the early developments of Old Colony identity. Zacharias suggests that historians often characterize Wiebe as "simply narrow-minded, obstinate, tradition-bound." Zacharias takes pains to emphasize that Wiebe considered himself to be a reformer-attempting to return the church to its New Testament vision, rather than simply trying to return to the old (Zacharias 2011, 193). Delbert Plett, the most strident apologist for the Old Colonists goes considerably further. He suggests Wiebe was "one of the most articulate and literate Mennonite leaders" who gathered together what became the Old Colony, "imprinting upon them in the 
process the teachings of genuine Biblicism" (Plett 2011a, 51). Others tend to emphasize the fundamentally conservative outlook of Wiebe. The entry in GAMEO (the online Mennonite encyclopedia) suggests Wiebe "did more than anyone else to develop and maintain the consistently conservative attitude that has characterized Old Colony Mennonites" (Krahn and Redekopp 2004). Certainly, Wiebe reinforced the use of the ban as a more Christian way of discipline compared to the practice of resorting to physical punishment, as had become the practice during the Johann Cornies' era in the 1840s (Plett 2011b, 54). His own writings do convey a sense of a deep belief that the Bible admonished Christians to avoid the world, and he had a clear sense of what that entailed. In his pastoral letter to the churches shortly before his death, Wiebe quotes liberally from scriptures that emphasize separateness from the world and decries when "the person's appearance is decorated and decked with all manner of adornment" and when "the luxurious life and clothing in particular, yes, extravagant clothing" are not named as being inappropriate for the Christian. Wiebe mourns how his contemporaries were "inherently predisposed toward walking with the world on the path of pleasure making." Like the seduction of Eve by the devil offering freedom to love the world, "so many churches" have treated the command to be separate from the world "with disdain, or doubtfully" (Lampe and Plett 2011, 66). As Zacharias rightly points out, Wiebe's conservative outlook was not strictly a return to the ways they had known in Russia, but rather, he reached back to the much earlier practices of church discipline and the use of the ban that had been practiced by more separatist-oriented Mennonites in The Netherlands and had caused so much trouble between them since the sixteenth century.

\section{Solidifying the Old Colony Identity}

A strict ranking of the factors that led to the emergence of a relatively stable and lasting Old Colony identity is not possible. However, the rapid changes of the late nineteenth and early twentieth centuries were the context for a reaction amongst a people that had a long history of worrying about "being conformed to this world." The changes wrought by the arrival of the railway and the state's determined intervention in education and local governance were deeply troubling to those Mennonites whose orientation leaned towards separation from the world. The reaction of their progressive, primarily Bergthaler, neighbors, who seemed too eager to adopt what they saw as the "ways of the world," was similarly troubling.

Certainly the school question, the imposition of the municipality, and the railway towns' stark display of the world were concrete problems that begged for solutions for the Mennonite Christian. The violation of what conserver-oriented Mennonites considered promises the government had made to them when they settled were viewed as betrayals. The internal conflict over singing proved to be the triggering issue for the internal strife that contributed to the emergence of the Old Colony Mennonite Church. Possibly, singing has not been given its due as a communitarian practice that offers wordless evidence of shared values and perspectives. The Ole Wies was never meant to be a performance of aesthetically pleasing sound, but rather was an 
emotional coming together of individuals in a communal act of worship. The disruption of the age-old rhythms of singing signified the loss of a shared identity that debates about local government and educational reform did not. Similarly, the adoption of Pietist forms of religious expression by their progressive neighbors assisted in propelling Old Colony Mennonites to a defensive traditional stance.

In the end, the nativism of World War I and the resulting imposition of state education offered the clearest boundary-making event for Old Colonists. By migrating to Mexico, you were clearly casting your lot with Johann Wiebe's church, even though he had already passed on. The tempo of using migration as a tool to find places to practice a conserver-oriented outlook, as well as a way of refining the faithful, increased. It took more than 200 years before Mennonites moved from Prussia to Russia, 85 years before the migration to Manitoba from the Russian Empire, and only 45 years before the migration to Mexico took place. The count-down in years before the next migration has continued to narrow, creating a vast diaspora of Old Colonists in the Americas.

The factors that gave rise to the Old Colony in Manitoba in the 1880s were not new. The problem of how to sing demonstrates most clearly the continuity of old and new world challenges. Mennonites in Russia had also been on a path to using education to support progress, while governments in both Russia and Canada tried to use education to foster patriotism. Renewal movements in Mennonite religious life could also not be avoided by migration. A short fifteen years after their arrival in Manitoba, the challenges of Russia again confronted them in Manitoba. Not being "of this world" steadily became more difficult.

\section{Endnote}

${ }^{1}$ Contact information: Hans Werner, Department of History, University of Winnipeg, 515 Portage Avenue, Winnipeg, Manitoba; h.werner@uwinnipeg.ca; (204) 786-9352

${ }^{2}$ The Old Colony Mennonites' Flemish origins were a particular emphasis of historian Delbert Plett. See, for instance, the special issue of Preservings he edited on the subject and his introduction (Plett 2003).

${ }^{3}$ For a concise account of the Frisian-Flemish split and the subsequent schism that resulted in the Old Flemish, see Koop (2004, 51-52). For an account of the role of Dirk Philips in attempts to resolve the dispute, see Keenley (1958).

${ }^{4}$ To avoid confusion, hereafter I refer to the initial colony established in Russia as Chortitza, rather than its common designation as the "Old Colony."

${ }^{5}$ The complete diary of Jacob Epp has been translated and published as Dyck (2013). In his earlier article, Toews lifted out and translated the diary entries pertaining to the singing controversy. Ohm was the Low German title for ministers in the church. 


\section{References}

Berg, Wesley. 1996. "Hymns of the Old Colony Mennonites and the Old Way of Singing." The Musical Quarterly 80(1):77-117. http://dx.doi.org/10.1093/mq/80.1.77

Dyck, Harvey (trans.). 2013. A Mennonite in Russia: The Diaries of Jacob Epp, 1851-1880. Toronto, ON: University of Toronto Press.

Dyck, Harvey. 1984. "Russian Servitor and Mennonite Hero: Light and Shadow in Images of Johann Cornies." Journal of Mennonite Studies 2:9-28.

Ens, Adolf. 1990. "The Tie that Binds: Prussian and Russian Mennonites, 1788-1794." Journal of Mennonite Studies 8:34-51.

Ens, Adolf. 1989. "Mennonite Education in Russia.” Pp. 75-97 in Mennonites in Russia: Essays in Honour of Gerhard Lohrenz, edited by John J. Friesen. Winnipeg, MB: CMBC Publications.

Ens, Adolf. 1994. Subjects or Citizens?: The Mennonite Experience in Canada, 1870-1925. Ottawa, ON: University of Ottawa Press.

Friesen, David. 1995. Journey of Faith: Winkler Bergthaler Mennonite Church, 1895-1995. Winkler, MB: Winkler Bergthaler Church.

Friesen, John J. 2011. "Reinlaender Mennoniten Gemeinde.” Pp. 3-19 in Old Colony Mennonites in Canada, 1875-2000, edited by Delbert Plett. Winnipeg, MB: D.F. Plett Historical Research Foundation, Inc.

Friesen, John J. 1989. "Mennonite Churches and Religious Developments in Russia, 17891850." Pp. 43-74 in Mennonites in Russia: Essays in Honour of Gerhard Lohrenz, edited by John J. Friesen. Winnipeg, MB: CMBC Publications.

Friesen, P.M. 1980. The Mennonite Brotherhood in Russia, 1789-1910. Fresno, CA: Board of Christian Literature, General Conference of Mennonite Brethren Churches.

Hofer, J.M. (ed. and trans.). 1931. “The Diary of Paul Tschetter, 1873-Part II.” Mennonite Quarterly Review 5(3):198-220.

Keenley, William. 1958. “Dirk Philips’ Life.” Mennonite Quarterly Review 32(3):171-91.

Koop, Karl. 2004. Anabaptist-Mennonite Confessions of Faith: The Development of a Tradition. Kitchener, ON: Pandora Press.

Krahn, Cornelius, and Alf Redekopp. 2004. "Wiebe, Johann (1837-1905).” Global Anabaptist Mennonite Encyclopedia Online. (http://gameo.org/index.php?title=Wiebe,_Johann_ (1837-1905)\&oldid=132641) 
Lampe, Ingrid, and Delbert Plett (trans.). 2011. "Johann Wiebe, Epistle to the Gemeinden, 1904." Pp. 55-57 in Old Colony Mennonites in Canada, 1875-2000, edited by Delbert Plett. Winnipeg, MB: D.F. Plett Historical Research Foundation, Inc.

Plett, Delbert. 2011a. "Editor's Foreward, to Aeltester Johann Wiebe (1837-1905), Documents." Pp. 51-52 in Old Colony Mennonites in Canada, 1875-2000, edited by Delbert Plett. Winnipeg, MB: D.F. Plett Historical Research Foundation, Inc.

Plett, Delbert (trans.). 2011b. “A Record of Our Journey from Russia to America.” Pp. 52-55 in Old Colony Mennonites in Canada, 1875-2000, edited by Delbert Plett. Winnipeg, MB: D.F. Plett Historical Research Foundation, Inc.

Plett, Delbert. 2003. “Our Flemish Roots-A Century of Struggle.” Preservings 22(June):1-2.

Redekop, Calvin. 1969. The Old Colony Mennonites: Dilemmas of Ethnic Minority Life. Baltimore, MD: Johns Hopkins University Press.

Schapansky, Henry. 2006. Mennonite Migrations (and the Old Colony). Rosenort, MB: Henry Schapansky.

Studer, Gerald. 1984. "The Dordrecht Confession of Faith, 1632-1982." Mennonite Quarterly Review 58(2):503-19.

Toews, John B. (ed. and trans.). 1985. "Harmony and Disharmony: A Diary Portrait of Mennonite Singing in Russia During the 1860s." Mennonite Life 40(4):4-7.

Toews, John B. 1984 "Brethren and Old Church Relations in Pre-World War I Russia: Setting the Stage for Canada." Journal of Mennonite Studies 2:42-59.

Urry, James. 1989. None but Saints: The Transformation of Mennonite Life in Russia, 17891889. Winnipeg, MB: Hyperion Press.

Zacharias, Peter D. 2011. "Biography of Johann Wiebe, 1837-1905), Rosengart.” Pp. 45-48 in Old Colony Mennonites in Canada 1875-2000, edited by Delbert Plett. Winnipeg, MB: D.F. Plett Historical Research Foundation, Inc.

Zacharias, Peter D. 1976. Reinland: An Experience in Community. Altona, MB: Reinland Centennial Committee. 